\title{
Effects of ensiling processes and antioxidants on fatty acid concentrations and compositions in corn silages
}

\author{
Liying Han and He Zhou*
}

\begin{abstract}
Background: Corn silage is the main dietary component used for ruminant breeding in China and is an important dietary source of fatty acids for these animals. However, little is known regarding effective means to protect the fatty acid (FA) contents in silages. In this study, we examined the changes in FA contents and compositions during corn ensiling and screened several antioxidants for their inhibition of lipid oxidation during corn ensiling.

Methods: We conducted two different experiments. In Experiment 1, corn was ensiled in 30 polyethylene bottles (bottle volume: $1 \mathrm{~L}$, silage density: $600 \mathrm{~g} / \mathrm{dm}^{3}$ ) and three bottles were opened at $0.5 \mathrm{~d}, 1 \mathrm{~d}, 1.5 \mathrm{~d}, 2 \mathrm{~d}, 2.5 \mathrm{~d}, 3 \mathrm{~d}, 5$ d, $7 \mathrm{~d}, 14 \mathrm{~d}$, and $28 \mathrm{~d}$ after ensiling. In Experiment 2, corn was treated with various antioxidants: (1) No additives (CK); (2) BHA (Butylated hydroxyanisole); (3) TBHQ (Tertiary butyl hydroquinone); (4) TPP (Tea polyphenols); and (5) VE (Vitamin E). These treatments were applied at $50 \mathrm{mg} / \mathrm{kg}$ and $100 \mathrm{mg} / \mathrm{kg}$ of fresh weight with each treatment replicated 3 times.
\end{abstract}

Results: During ensiling in Experiment 1, saturated fatty acids (SFA; C16:0 and C18:0) and malondialdehyde (MDA) contents tended to increase, whereas unsaturated fatty acids (UFA; C18:1, C18:2 and C18:3) tended to decrease. However, these changes were only significant on the first 2 days of ensiling. In Experiment 2, all of the antioxidants tested affected the total FA contents and those of unsaturated fatty acids (C18:1, C18:2 and C18:3) and MDA. The effects of TBHQ and TPP were greater than those of the other antioxidants.

Conclusions: The reduced total FA contents in corn silages were due to unsaturated fatty acids' oxidation during the early stages of ensiling. Adding an antioxidant could prevent fatty acids' oxidation in corn silages.

Keywords: Antioxidant, Fatty acid, Silage

\section{Background}

Corn silage is the main dietary component used for ruminant breeding in China and is an important dietary source of fatty acids for these animals. However, the ensiling process may reduce the positive effects of herbage lipids on the fatty acid (FA) composition of milk due to oxidation during the period between plant cutting and ensiling [1,2]. During harvesting and the early stages of ensiling, enzymatic hydrolysis of triacylglycerols yield free fatty acids (FFAs) from damaged tissues after cutting and non-esterified polyunsaturated fatty acids (PUFA) from damaged membranes are rapidly converted to hydroperoxy PUFA by the

\footnotetext{
* Correspondence: zhouhe@cau.edu.cn

College of Animal Science and Technology, China Agricultural University, Yuanmingyuan West Road 2\#, Haidian District Beijing, PRC, 100193, China
}

actions of lipoxygenases (LOX) [3]. The most common substrates for plant lipoxygenases are linolenic and linoleic acids. These are abundant in plant membranes and can be further broken down into aldehydes and ketones [4], which may affect feed preferences, palatability, and ingestion by animals $[5,6]$.

Numerous studies have been done on chemically characterizing silages and their nutritional value in order to obtain high quality silages [7-9]. Dewhurst et al. [10] concluded that plant species and cutting intervals affected the FA compositions of grasses. The effects of additives, such as formalin, formic acid, inoculants, and enzymes, on the FA compositions of grass silages have also been investigated [11-14], although these results suggested that they only had minimal effects on the FA contents. 
Lourenco et al. [15] and Lee et al. [16] attributed reduced lipid oxidation in red or white clover silages to their high polyphenol oxidase (PPO) contents. However, due to wilting and ensiling, ensiled forages contain fewer antioxidants as compared to fresh pasture forage $[13,17]$. Some antioxidant phenolic compounds have been widely used to inhibit lipid oxidation in the food industry. Thus, it might be possible to use these as silo lipid oxidation inhibitors.

Thus, in this study, we examined the changes in FA contents and compositions during corn ensiling and screened several antioxidants for their inhibition of lipid oxidation during corn ensiling.

\section{Methods}

\section{Corn and ensiling}

We used corn for our experiments (Zea mays L., JKN928), which was sown on April 25, 2012. The temperature range and total precipitation during the growing season were $16.2-27.4^{\circ} \mathrm{C}$ and $94.5 \mathrm{~mm}$, respectively. We selected a high cutting height for corn (1 m above ground) in order to increase the FA contents during ensiling. To determine their compositions, 10 plants from 10 randomly selected sites were sampled, chopped, and stored at $-80^{\circ} \mathrm{C}$. Corn, including the ear, was harvested at the one-half milk line stage (August 5,2012 ) and chopped into $10 \mathrm{~mm}$ lengths using a conventional forage harvester. Then, we used two different experiments.

In Experiment 1, corn was ensiled in 30 polyethylene bottles (bottle volume: $1 \mathrm{~L}$, silage density: $600 \mathrm{~g} / \mathrm{dm}^{3}$ ) in the dark at $25 \pm 2^{\circ} \mathrm{C}$. Each treatment was replicated 3 times. Three bottles were opened after having been ensiled for $0.5 \mathrm{~d}, 1 \mathrm{~d}, 1.5 \mathrm{~d}, 2 \mathrm{~d}, 2.5 \mathrm{~d}, 3 \mathrm{~d}, 5 \mathrm{~d}, 7 \mathrm{~d}, 14 \mathrm{~d}$, and $28 \mathrm{~d}$. About $400 \mathrm{~g}$ samples from each bottle were removed and vacuum packed at $-18^{\circ} \mathrm{C}$ to determine the fermentation quality, FA contents and compositions, and malondialdehyde (MDA) contents.

In Experiment 2, corn was divided into equal portions for different treatments. These treatments were: (1) No additives (CK); (2) Butylated hydroxyanisole (BHA, synthetic antioxidant); (3) Tertiary butyl hydroquinone (TBHQ, synthetic antioxidant); (4) Tea polyphenols (TPP, natural antioxidant); and (5) Vitamin E (VE, natural antioxidant). These treatments were applied at $50 \mathrm{mg} / \mathrm{kg}$ and $100 \mathrm{mg} / \mathrm{kg}$ of fresh weight. All antioxidants were purchased from Beijing Sky Bamboo Bird Food Additives Co., Ltd. (Beijing, China). The antioxidants were diluted with distilled water to obtain the designated application concentrations and sprayed onto fresh corn. For a control, the same amount of distilled water was sprayed onto corn samples. About $200 \mathrm{~g}$ of each treated or untreated corn sample was frozen immediately in liquid nitrogen and used to determine LOX activity.
Treated and untreated corn samples were ensiled in polyethylene bottles (bottle volume: $1 \mathrm{~L}$, silage density: $600 \mathrm{~g} / \mathrm{dm}^{3}$ ) in the dark at $25 \pm 2^{\circ} \mathrm{C}$ for $60 \mathrm{~d}$. Each treatment was replicated 3 times. The FA contents and compositions (C16:0, C18:0, C16:1, C18:1, C18:2, C18:3), and the contents of MDA, fermentation quality, dry matter (DM), water soluble carbohydrates (WSC), crude proteins (CP), neutral detergent fiber (NDF), and acid detergent fiber $(\mathrm{ADF})$ in these silages were determined when the silage bottles were opened.

\section{Chemical analyses}

Using $250 \mu \mathrm{mol} / \mathrm{L}$ linolenic acid as the substrate, lipoxygenase (LOX) activity was determined as the increase in absorbance at $234 \mathrm{~nm}$ due to the formation of conjugated dienes using a spectrophotometer over 5-10 $\mathrm{min}$ [18]. A sample $(1 \mathrm{~g})$ was diluted in $50 \mathrm{mmol} / \mathrm{L} \mathrm{Na}$ phosphate buffer ( $\mathrm{pH}$ 7.0) and incubated for $30 \mathrm{~min}$ on ice with occasional vortexing. The sample was then centrifuged $(10,000 \mathrm{rpm})$ at $4^{\circ} \mathrm{C}$ for $30 \mathrm{~min}$ and the supernatant was used as a crude enzyme solution. Protein concentrations in the enzyme solutions were determined using the Bradford method (Bio-Rad, Hercules, CA, USA).

To initiate the assay, $0.05 \mathrm{~mL}$ of an enzyme extract was mixed with $0.25 \mathrm{~mL}$ of substrate stock solution, followed by incubation at $30^{\circ} \mathrm{C}$ for $4 \mathrm{~min}$. After incubation, $1 \mathrm{~mol} / \mathrm{L}$ $\mathrm{NaOH}(0.7 \mathrm{~mL})$ was added to stop the reaction. Hydroperoxides produced by LOX were monitored using a spectrophotometer (Thermo Electron Co., PA, USA) at $234 \mathrm{~nm}$. One unit of enzyme activity was defined as an increase in absorbance of 0.001 at $234 \mathrm{~nm}$ per $\mathrm{mg}$ of protein per minute (Units/mg protein/min). Protein concentrations were determined using the Coomassie Brilliant Blue method [19].

FA compositions were determined by gas chromatography (GC) after methylation [20]. GC analyses were done using a Shimadzu GC-2010 chromatograph equipped with an Agilent chromatography column for FA methyl esters (FAME) $(100 \mathrm{~m} \times 0.25 \mathrm{~mm} \times 0.2 \mu \mathrm{m})$. The temperature program was: starting temperature of $180^{\circ} \mathrm{C}$ for 10 min, which was then increased by $4^{\circ} \mathrm{C} / \mathrm{min}$ until the temperature reached $200^{\circ} \mathrm{C}$; the injector temperature was set at $250^{\circ} \mathrm{C}$; and the detector temperature was $280^{\circ} \mathrm{C}$. Malondialdehyde (MDA) was determined spectrophotometrically as thiobarbituric acid reactive substances (TBARS) after reaction with thiobarbituric acid (TBA) at $100^{\circ} \mathrm{C}$ in acidic media; the absorbance of a reaction mixture was measured at $532 \mathrm{~nm}$ [21].

Fermentation indices were determined using the following methods. A sample silage ( $20 \mathrm{~g}$ ) was homogenized in $180 \mathrm{~mL}$ of distilled water for $1 \mathrm{~min}$ at high speed $(12,000 \mathrm{rpm})$. The resulting suspension was filtered through four layers of cheese cloth and then centrifuged for $20 \mathrm{~min}$ at $27,500 \times \mathrm{g}$, after which the pellet discarded. 
Supernatant samples were used for $\mathrm{pH}$, lactic acid, acetic acid, propionic acid, butyric acid, and $\mathrm{NH}_{3}-\mathrm{N}$ analyses. $\mathrm{pH}$ was determined with a $\mathrm{pH}$ meter (PHS-3C). Lactic acid, acetic acid, propionic acid, and butyric acid were determined by HPLC (SHIMADZE-10A, Shimadze, Japan) as described [22]. The HPLC system included a Shimadzu system controller (SCL-10A) and a Shodex Rspak KC-811 S-DVB gel column $(300 \mathrm{~mm} \times 8 \mathrm{~mm})$ at a column temperature of $50^{\circ} \mathrm{C}$. The mobile phase was a solution of $3 \mathrm{mmol}$ perchloric acid at a rate of $1 \mathrm{~mL} / \mathrm{min}$. The injection volume was $50 \mu \mathrm{L}$. A UV detector (SPD10A) was used and analyses were made at $210 \mathrm{~nm}$.

Ammonia-N $\left(\mathrm{NH}_{3}-\mathrm{N}\right)$ was determined by the PhenolHypochlorite colorimetric method as described [23]. DM was determined by oven drying at $65^{\circ} \mathrm{C}$ for $48 \mathrm{~h}$. Crude protein $(\mathrm{CP})$ was determined using the Kjeldahl method [24]. NDF and ADF were analyzed as described [25]. Water-soluble carbohydrate (WSC) was determined by the Deriaz method [26].

\section{Statistical analysis}

Statistical comparisons were made by one-way analysis of variance followed by Duncan's new multiple range test [27]. Results for similar treatments at different time points were compared using paired t-tests. Statistical analyses were done using SAS 9.1.3 software (SAS Institute, Cary, NC, USA). $P<0.05$ was considered significant.

\section{Results}

\section{Material compositions}

Dry matter (DM) contents and the chemical compositions (WSC, CP, NDF, ADF, and FA contents and compositions) of fresh chopped whole corn plants before ensiling are shown in Table 1. The DM contents and WSC of the corn used in this study were higher than the recommended contents to ensure successful ensiling and to obtain good fermentation rates $[28,29]$. High CP and total FA contents and low NDF and ADF contents were found because of the high cutting height used in this study $(1 \mathrm{~m}$ above ground). More than one half of the FA in fresh corn was C18:2.

\section{Fatty acid changes during ensiling}

The FA contents and compositions and the MDA contents during ensiling are shown in Table 2. No differences were found for DM during ensiling, whereas significant decreases in WSC and $\mathrm{pH}$ had occurred, as was expected. Total FA contents decreased markedly during the first two days of ensiling. Significant changes in C16:0, C18:0, C18:1, C18:2, and C18:3 compositions were also found during the first two or three days of ensiling. Saturated fatty acid (SFA; C16:0 and C18:0) compositions tended to increase, whereas unsaturated fatty acid (UFA; C18:1, C18:2, and C18:3) compositions tended to
Table 1 DM, WSC, CP, NDF, ADF, FA contents and compositions in fresh whole plant corn

\begin{tabular}{|c|c|c|c|}
\hline Items & $\mathrm{N}^{1}$ & Mean & $\mathrm{SD}^{2}$ \\
\hline $\mathrm{DM}, \mathrm{g} / \mathrm{kg}$ & 10 & 283.3 & 12.6 \\
\hline WSC, g/kg DM & 10 & 130.4 & 4.0 \\
\hline$C P, g / k g ~ D M$ & 10 & 115.4 & 7.5 \\
\hline NDF, g/kg DM & 10 & 384.1 & 4.5 \\
\hline ADF, g/kg DM & 10 & 271.2 & 2.1 \\
\hline Total FA content, mg/kg DM & 10 & 24.74 & 0.61 \\
\hline \multicolumn{4}{|l|}{ Proportion in DM, mg/kg DM } \\
\hline C16:0 & 10 & 4.16 & 0.16 \\
\hline C18:0 & 10 & 1.61 & 0.11 \\
\hline C18:1 & 10 & 3.86 & 0.27 \\
\hline $\mathrm{C} 18: 2$ & 10 & 12.97 & 0.14 \\
\hline C18:3 & 10 & 1.85 & 0.08 \\
\hline \multicolumn{4}{|l|}{ Proportion in total FA,\% } \\
\hline C16:0 & 10 & 16.81 & 1.56 \\
\hline C18:0 & 10 & 6.51 & 0.73 \\
\hline C18:1 & 10 & 14.87 & 1.03 \\
\hline C18:2 & 10 & 52.43 & 3.45 \\
\hline C18:3 & 10 & 7.48 & 0.74 \\
\hline
\end{tabular}

${ }^{1} N$, observation numbers.

${ }^{2} S D$, standard deviation.

decrease. The greatest decrease in the proportion of C18:2 among total FA occurred on the 28th day of ensiling. The proportion of MDA increased as the number of days of ensiling increased, although this was only significant during the first two days.

\section{Lipoxygenase (LOX) activity}

LOX activity results are shown in Table 3 . The LOX activities of treated corn were lower than that of the control. LOX activity decreased as the concentration of additives increased for most treatments used. However, LOX activities were not detected when the added concentrations of TPP and BTHQ were $100 \mathrm{mg} / \mathrm{kg}$.

\section{Effects of antioxidants}

The fermentation quality and chemical compositions of the corn silages after $60 \mathrm{~d}$ of conservation are shown in Table 4. The $\mathrm{pH}$ values of all the silages when bottles were opened were $<4.0$. The lactic acid (LA) contents were high, and there was little butyric acid (BA) $(<0.1 \mathrm{~g} / \mathrm{kg}$ $\mathrm{DM})$. All of the treatments used affected ammoniacal nitrogen/total nitrogen $\left(\mathrm{NH}_{3}-\mathrm{N} / \mathrm{TN}\right)$ and WSC contents. There were no significant differences between treated and untreated silages for DM, CP, NDF, and ADF contents.

The effects of the different antioxidants on the FA contents and compositions and the MDA contents are shown in Table 5. All of these antioxidants affected the 
Table 2 Effect of the ensiling process on total FA content and composition, MDA, DM and WSC content in corn silage

\begin{tabular}{|c|c|c|c|c|c|c|c|c|c|c|}
\hline Treatments & $0.5 d$ & $1 d$ & $1.5 d$ & $2 d$ & $3 d$ & $5 d$ & $7 d$ & 14d & 28d & SEM $^{1}$ \\
\hline$\overline{\mathrm{pH}}$ & $4.61^{a}$ & $4.25^{b}$ & $4.08^{c}$ & $3.85^{\mathrm{d}}$ & $3.76^{\mathrm{de}}$ & $3.73^{\text {de }}$ & $3.70^{e}$ & $3.69^{e}$ & $3.68^{c}$ & 0.06 \\
\hline Total FA, mg/kg DM & $23.68^{\mathrm{a}}$ & $23.04^{\mathrm{a}}$ & $21.73^{b}$ & $19.56^{\mathrm{C}}$ & $19.43^{c}$ & $19.45^{c}$ & $19.51^{c}$ & $19.57^{c}$ & $19.75^{c}$ & 0.76 \\
\hline \multicolumn{11}{|c|}{ Proportion in DM, mg/kg DM } \\
\hline C16:0 & $4.19^{c}$ & $4.27^{b}$ & $4.36^{\mathrm{b}}$ & $4.55^{\mathrm{a}}$ & $4.56^{\mathrm{a}}$ & $4.58^{\mathrm{a}}$ & $4.59^{\mathrm{a}}$ & $4.62^{a}$ & $4.66^{\mathrm{a}}$ & 0.18 \\
\hline C18:0 & $1.73^{\mathrm{C}}$ & $1.78^{\mathrm{c}}$ & $1.88^{\mathrm{b}}$ & $1.85^{\mathrm{b}}$ & $1.91^{\mathrm{a}}$ & $2.04^{a}$ & $2.02^{\mathrm{a}}$ & $2.05^{\mathrm{a}}$ & $2.09^{\mathrm{a}}$ & 0.09 \\
\hline C18:1 & $3.34^{\mathrm{a}}$ & $3.01^{b}$ & $2.99^{b}$ & $2.57^{c}$ & $2.45^{c}$ & $2.48^{c}$ & $2.46^{\mathrm{c}}$ & $2.45^{c}$ & $2.56^{\mathrm{C}}$ & 0.21 \\
\hline C18:2 & $11.92^{\mathrm{a}}$ & $10.64^{b}$ & $9.74^{c}$ & $8.53^{d}$ & $8.34^{d}$ & $8.23^{d}$ & $8.18^{d}$ & $8.19^{d}$ & $8.21^{d}$ & 0.26 \\
\hline C18:3 & $1.78^{a}$ & $1.59^{b}$ & $1.44^{c}$ & $1.32^{\mathrm{d}}$ & $1.31^{\mathrm{d}}$ & $1.27^{d}$ & $1.23^{\mathrm{d}}$ & $1.19^{d}$ & $1.18^{\mathrm{d}}$ & 0.20 \\
\hline \multicolumn{11}{|c|}{ Proportion in total FA,\% } \\
\hline C16:0 & $17.69^{d}$ & $18.53^{c}$ & $20.06^{b}$ & $23.26^{\mathrm{a}}$ & $23.46^{a}$ & $23.54^{\mathrm{a}}$ & $23.52^{\mathrm{a}}$ & $23.60^{\mathrm{a}}$ & $23.59^{\mathrm{a}}$ & 0.41 \\
\hline C18:0 & $7.31^{d}$ & $7.73^{d}$ & $8.65^{c}$ & $9.46^{\mathrm{b}}$ & $9.83^{\mathrm{a}}$ & $10.49^{a}$ & $10.35^{\mathrm{a}}$ & $10.47^{a}$ & $10.58^{\mathrm{a}}$ & 0.52 \\
\hline C18:1 & $14.10^{\mathrm{a}}$ & $13.06^{b}$ & $12.84^{\mathrm{b}}$ & $13.14^{\mathrm{b}}$ & $12.61^{b}$ & $12.24^{b}$ & $12.61^{b}$ & $12.52^{b}$ & $12.96^{b}$ & 0.35 \\
\hline C18:2 & $50.33^{\mathrm{a}}$ & $46.18^{b}$ & $44.82^{c}$ & $43.61^{d}$ & $42.92^{d}$ & $42.31^{d}$ & $41.93^{d}$ & $41.84^{d}$ & $41.56^{d}$ & 0.62 \\
\hline C18:3 & $7.52^{\mathrm{a}}$ & $6.90^{\mathrm{b}}$ & $6.63^{b}$ & $6.74^{b}$ & $6.74^{b}$ & $6.53^{\mathrm{b}}$ & $6.30^{\mathrm{b}}$ & $6.08^{b}$ & $5.97^{\mathrm{b}}$ & 0.24 \\
\hline $\mathrm{MDA}, \mu \mathrm{mol} / \mathrm{g} \mathrm{FW}$ & $35.12^{d}$ & $47.33^{c}$ & $60.82^{b}$ & $72.11^{\mathrm{a}}$ & $72.18^{\mathrm{a}}$ & $73.39^{a}$ & $73.69^{a}$ & $74.60^{a}$ & $74.89^{\mathrm{a}}$ & 0.52 \\
\hline DM, g/kg FW & 28.83 & 28.45 & 27.72 & 27.69 & 28.71 & 28.16 & 29.80 & 28.00 & 27.72 & 1.69 \\
\hline WSC, g/kg DM & $9.93^{\mathrm{a}}$ & $9.62^{a}$ & $9.24^{\mathrm{a}}$ & $6.73^{b}$ & $6.71^{b}$ & $5.27^{\mathrm{bc}}$ & $4.76^{\mathrm{C}}$ & $2.29^{d}$ & $2.01^{d}$ & 0.86 \\
\hline
\end{tabular}

Table 3 Effect of different antioxident additives on the LOX activity in corn silage

\begin{tabular}{lll}
\hline Additives & Amount & LOX activity, $\%$ \\
\hline BHA & $0, \mathrm{Ck}^{1}$ & $100^{\mathrm{a}}$ \\
& $50 \mathrm{mg} / \mathrm{kg}$ & $46.32^{\mathrm{b}}$ \\
& $100 \mathrm{mg} / \mathrm{kg}$ & $23.71^{\mathrm{c}}$ \\
$\mathrm{SE}^{2}$ & & 9.15 \\
& & \\
TBHQ & $0, \mathrm{Ck}$ & $100^{\mathrm{a}}$ \\
& $50 \mathrm{mg} / \mathrm{kg}$ & $26.15^{\mathrm{b}}$ \\
& $100 \mathrm{mg} / \mathrm{kg}$ & $0.00^{\mathrm{c}}$ \\
$\mathrm{SE}$ & & 8.47 \\
& & \\
$\mathrm{TPP}$ & $0, \mathrm{Ck}$ & $100^{\mathrm{a}}$ \\
& $50 \mathrm{mg} / \mathrm{kg}$ & $22.04^{\mathrm{b}}$ \\
& $100 \mathrm{mg} / \mathrm{kg}$ & $0.00^{\mathrm{c}}$ \\
$\mathrm{SE}$ & & 10.26 \\
& & $100^{\mathrm{a}}$ \\
VE & & $37.69^{\mathrm{b}}$ \\
& & $15.33^{\mathrm{c}}$ \\
& & 9.15 \\
\hline
\end{tabular}

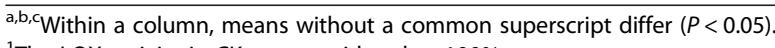

${ }^{1}$ The LOX activity in CK was considered as $100 \%$.

${ }^{2} S E$, standard error. total FA contents and treatments with TBHQ100 and TPP100 were better than the other antioxidants. There were no significant differences in saturated fatty acids (C16:0 and C18:0) between treated and untreated silages, whereas the unsaturated fatty acid (C18:1, C18:2 and C18:3) compositions of treated silages were higher than those of the control. The MDA contents in treated silages were lower than in the control.

\section{Discussion}

Corn that is ensiled along with the ear can improve the nutritional value of feed because the high WSC contents should increase bacterial activity. In this study, high WSC and $\mathrm{CP}$ contents and low NDF and ADF contents resulted because of the high cutting height we used. Linoleic acid (C18:2) in corn increases as the plant matures, whereas the C18:3 concentration progressively declines [30]. Thus, C18:2 corresponded to more than $50 \%$ of the total FA in this study, which was in agreement with Shingfield et al. [13].

Lipid oxidation depends on the activity of lipoxygenases. Lipoxygenase activity is found in a plant at all growth stages and this activity increases when a plant enters the mature and senescence stages or after tissue injury. UFA's that are hydrolyzed from lipids are oxidized by LOX to form hydroperoxides, which are further decomposed into aldehydes and ketones. Malondialdehyde (MDA) is primarily produced via the lipoxygenase pathway of fatty acid oxidation and is widely used in food science as an 
Table 4 Effect of different antioxidants on the formation of corn silage

\begin{tabular}{|c|c|c|c|c|c|c|c|c|c|c|}
\hline Treatments & $\mathrm{pH}$ & $\begin{array}{l}\text { LA } \\
\mathrm{g} / \mathrm{kg} \\
\mathrm{DM}\end{array}$ & $\begin{array}{l}\text { AA } \\
\mathrm{g} / \mathrm{kg} \\
\mathrm{DM}\end{array}$ & $\begin{array}{l}\text { BA } \\
\mathrm{g} / \mathrm{kg} \\
\mathrm{DM}\end{array}$ & $\begin{array}{l}\mathrm{NH}_{3}-\mathrm{N} \\
\mathrm{g} / \mathrm{kg} \\
\mathrm{TN}\end{array}$ & $\begin{array}{l}\text { DM } \\
\mathrm{g} / \mathrm{kg} \\
\mathrm{FW}\end{array}$ & $\begin{array}{l}\text { WSC } \\
\text { g/kg } \\
\text { DM }\end{array}$ & $\begin{array}{l}\mathrm{CP} \\
\mathrm{g} / \mathrm{kg} \\
\mathrm{DM}\end{array}$ & $\begin{array}{l}\text { NDF } \\
\text { g/kg } \\
\text { DM }\end{array}$ & $\begin{array}{l}\text { ADF } \\
\mathrm{g} / \mathrm{kg} \\
\mathrm{DM}\end{array}$ \\
\hline$\overline{C K}$ & 3.75 & 46.3 & 24.1 & $<0.1$ & $36.1^{a}$ & 281.7 & $10.3 c$ & 132.4 & 394.1 & 221.7 \\
\hline BHA50 & 3.62 & 47.1 & 23.4 & $<0.1$ & $24.1^{b}$ & 285.3 & $13.7 \mathrm{~b}$ & 139.8 & 381.5 & 218.5 \\
\hline BHA100 & 3.60 & 46.9 & 22.5 & $<0.1$ & $21.2^{c}$ & 290.7 & $14.3 \mathrm{a}$ & 145.2 & 378.6 & 209.5 \\
\hline TBHQ50 & 3.71 & 46.4 & 22.0 & $<0.1$ & $25.4^{\mathrm{b}}$ & 282.4 & $13.2 \mathrm{~b}$ & 138.6 & 385.3 & 219.6 \\
\hline TBHQ100 & 3.70 & 46.3 & 21.3 & $<0.1$ & $20.1^{c}$ & 291.1 & $14.1 \mathrm{a}$ & 140.9 & 382.6 & 205.4 \\
\hline TPP50 & 3.72 & 48.2 & 24.8 & $<0.1$ & $20.3^{c}$ & 292.1 & $14.5 \mathrm{a}$ & 141.5 & 379.5 & 212.5 \\
\hline TPP100 & 3.70 & 47.8 & 23.9 & $<0.1$ & $19.7^{c}$ & 296.9 & $15.2 \mathrm{a}$ & 146.3 & 375.1 & 200.1 \\
\hline VE50 & 3.74 & 47.6 & 25.0 & $<0.1$ & $21.1^{c}$ & 288.6 & $12.9 \mathrm{~b}$ & 136.6 & 388.9 & 214.7 \\
\hline VE100 & 3.71 & 47.5 & 24.5 & $<0.1$ & $20.5^{c}$ & 294.3 & $14.7 \mathrm{a}$ & 142.5 & 379.1 & 203.5 \\
\hline${ }^{1}$ SEM & 0.42 & 4.13 & 2.51 & - & 1.33 & 6.72 & 1.72 & 4.12 & 7.25 & 6.57 \\
\hline
\end{tabular}

a,b,c Within a column, means without a common superscript differ $(P<0.05)$.

${ }^{1}$ SEM, standard error mean.

index of lipid oxidation and rancidity in foods and food products [31]. Thus, for this study, MDA was determined as a product of lipid peroxidation and used as an index of lipid oxidation.

The differences in FA compositions could be related to various factors, such as plant species, cutting date, wilting, and the ensiling process [10,11,32-34]. Plant enzymes can remain functional in silages, although the activity of plant enzymes generally declines during ensiling. According to Elgersma et al [35], almost all of the total fat in fresh grass is in the form of esterified fatty acids, whereas in silage, a large proportion is in the form of free fatty acids (FFAs). These FFAs are then further oxidized by LOX.

UFAs are more susceptible to oxidation than are SFAs. Thus, the decrease in total FA contents together with the increase in SFA contents and the decreases in UFA

Table 5 Effect of diierent antioxidants on the FA content and composition and MDA content of corn silages (mg/kg DM)

\begin{tabular}{|c|c|c|c|c|c|c|c|}
\hline Treatments & Total FA & C16:0 & C18:0 & C18:1 & C18:2 & C18:3 & $\begin{array}{c}\mathrm{MDA}, \\
\mu \mathrm{mol} / \mathrm{g} \\
\mathrm{FW}\end{array}$ \\
\hline$\overline{C K}$ & $19.37^{c}$ & 3.34 & 1.62 & $2.89^{c}$ & $9.06^{d}$ & $1.52^{c}$ & $68.99^{a}$ \\
\hline BHA50 & $21.81^{b}$ & 3.36 & 1.65 & $3.06^{b}$ & $10.73^{c}$ & $1.65^{\mathrm{b}}$ & $46.69^{b}$ \\
\hline BHA100 & $22.12^{\mathrm{a}}$ & 3.29 & 1.56 & $3.15^{\mathrm{b}}$ & $11.65^{b}$ & $1.67^{\mathrm{b}}$ & $34.45^{c}$ \\
\hline TBHQ50 & $22.74^{\mathrm{a}}$ & 3.41 & 1.58 & $2.99^{\mathrm{b}}$ & $11.68^{b}$ & $1.79^{\mathrm{a}}$ & $32.75^{c}$ \\
\hline TBHQ100 & $23.04^{\mathrm{a}}$ & 3.30 & 1.51 & $3.11^{\mathrm{b}}$ & $11.95^{\mathrm{a}}$ & $1.82^{\mathrm{a}}$ & $32.31^{c}$ \\
\hline TPP50 & $22.56^{\mathrm{a}}$ & 3.35 & 1.55 & $3.22^{\mathrm{b}}$ & $11.62^{b}$ & $1.80^{\mathrm{a}}$ & $32.44^{c}$ \\
\hline TPP100 & $23.05^{\mathrm{a}}$ & 3.22 & 1.50 & $3.56^{\mathrm{a}}$ & $12.02^{a}$ & $1.85^{\mathrm{a}}$ & $31.82^{c}$ \\
\hline VE50 & $21.95^{\mathrm{b}}$ & 3.38 & 1.60 & $3.02^{b}$ & $10.69^{c}$ & $1.63^{b}$ & $45.68^{b}$ \\
\hline VE100 & $22.74^{a}$ & 3.25 & 1.57 & $3.23^{b}$ & $11.33^{b}$ & $1.72^{\mathrm{b}}$ & $34.12^{c}$ \\
\hline 'SEM & 0.65 & 0.17 & 0.09 & 0.27 & 1.33 & 0.12 & 2.41 \\
\hline
\end{tabular}

${ }^{a, b, c, d}$ Within a column, means without a common superscript differ $(P<0.05)$. ${ }^{1} S E M$, standard error mean. contents on $28 \mathrm{~d}$ of corn ensiling were due to UFA oxidation, particularly that of C18:2. Malondialdehyde (MDA), one of the final products of lipid oxidation, increased during ensiling, which further indicated FA oxidation during ensiling. The rapid changes in FA contents and compositions mainly occurred during the first two days of ensiling in this study. This indicated that enzyme activity was higher during the first two days than during the other ensiling periods. This may have been related to the $\mathrm{pH}$ changes that occurred during ensiling.

A high LOX activity would be plausible in high $\mathrm{pH}$ silages, whereas these enzymes would be inhibited by low $\mathrm{pH}[15,36]$. In addition, lipid or FA oxidation requires oxygen, whereas ensiling is a process that progresses from aerobic conditions to anaerobic conditions. Thus, LOX activity would decline as oxygen was consumed during ensiling.

Many additives, such as formalin, formic acid, inoculants, and enzymes, have been used to alter the FA contents and compositions of silages [11-14]. However, their effects were either minimal or they had no effects. Among the various methods that have recently been used to prevent lipid peroxidation, adding antioxidants has received the most attention. Most of the commonly used antioxidants are phenolics that can be divided into synthetic compounds and natural ingredients.

Synthetic compounds, such as BHA, BHT, and TBHQ, are chemically stable, inexpensive, and readily available. However, the safety of these synthetic antioxidants has been questioned due to their potential risks to human health [37]. Thus, there is a growing interest in natural ingredients because they are more acceptable to consumers, more palatable, stable. and improve the shelf-lives of food products. They have also shown beneficial health effects against degenerative diseases and certain cancers. 
Polyphenols are known to have important protective roles during lipoperoxidation. There is considerable data for the use of polyphenols as natural antioxidants and an interest in the antioxidant properties of polyphenols from pomegranate has recently emerged $[38,39]$. Vitamin $\mathrm{E}$ is commonly added to animal and human diets because it can inhibit lipoperoxidation [40]. It is also an important nutrient that aids in stabilizing unsaturated fatty acids in milk $[41,42]$.

Antioxidants prevent enzyme catalysis by disrupting fatty acid peroxidation chain reactions or chelating $\mathrm{Cu}$ and Fe ions to form stable chelation compounds $[43,44]$. The lipoperoxidase (LOX) activities found in this study were lower after adding antioxidants as compared to the control. These results were consistent with those in a previous report [45], which indicated that antioxidants considerably inhibited lipid oxygenation.

All of the silages in this study were of high quality due to their high lactic acid contents, low $\mathrm{pH}$ values, and $\mathrm{NH}_{3}-\mathrm{N} / \mathrm{TN}$ contents. Furthermore, as compared to the control, all of the treatments we used affected the $\mathrm{NH}_{3}$ $\mathrm{N} / \mathrm{TN}$ contents. The reason may have been that the antioxidants used in this study inhibited protease activity. For the same reason, the treated silages had higher $\mathrm{CP}$ contents than the control, although these differences were not significant. Aerobic microorganism metabolism would also be restricted because of the lower oxygen tension. Thus, the WSC contents in treated silages were higher than they were in the control on day 28 of this study. The antioxidants used in this study could not break down cellulose, so there were no significant differences between treated and untreated silages for NDF and ADF contents.

We found that all of the antioxidants we used successfully protected fatty acids. Higher total FA and UFA contents, and lower MDA contents were found in all of the treated silages. These results were consistent with the predicted loss of antioxidants in silage during ensiling [13,17]. Furthermore, TPP and TBHQ were better than BHA and VE for inhibiting FA oxidation. These results were consistent with the inhibitory effects on LOX activity shown in Table 3, which indicated that the FA losses in silages were mainly due to the effects on LOX activity and that higher FA concentrations could be obtained by inhibiting LOX activity.

\section{Conclusions}

A reduction in total FA contents in corn silages was due to the oxidation of unsaturated fatty acids by LOX during the early stages of ensiling. However, adding an antioxidant could prevent fatty acids' oxidation in corn silages.

\section{Abbreviations}

DM: Dry matter; FW: Fresh weight; WSC: Water-soluble carbohydrate; CP: Crude protein; NDF: Neutral detergent fiber; ADF: Acid detergent fiber; FA: Fatty acid; MDA: Malondialdehyde; LOX: Lipoperoxidation; LA: Lactic acid; AA: Acetic acid; BA: Butyric acid; NH3-N/TN: Ammoniacal nitrogen/total nitrogen; CK: No additives; BHA: Butylated hydroxyanisole; TBHQ: Tertiary butyl hydroquinone; TPP: Teapolyphenols; VE: Vitamin E; BHA50: $50 \mathrm{mg}$ butylated hydroxyanisole/kg fresh corn; BHA100: 100 mg butylated hydroxyanisole/kg fresh corn; TBHQ50: 50 mg tertiary butyl hydroquinone/kg fresh corn; TBHQ100: $100 \mathrm{mg}$ tertiary butyl hydroquinone/kg fresh corn; TPP50: $50 \mathrm{mg}$ teaPolyphenols / $\mathrm{kg}$ fresh corn; TPP100: $100 \mathrm{mg}$ teaPolyphenols/kg fresh corn; VE50: $50 \mathrm{mg}$ vitamin E/kg fresh corn; VE100: $100 \mathrm{mg}$ vitamin E/kg fresh corn.

\section{Competing interests}

The authors declare that they have no competing interests related to this study.

\section{Authors' contributions}

LYH did the chemical analyses, statistical analyses, and drafted the manuscript. $\mathrm{HZ}$ conceived the study, participated in its design and coordination, and helped draft the manuscript. All authors read and approved the final manuscript.

\section{Acknowledgments}

Funding for this research by the National Science and Technology Foundation (2011BAD17B02) and the Research Fund for the Doctoral Program of Higher Education of China (20120008110003) is gratefully acknowledged.

\section{Received: 4 July 2013 Accepted: 2 December 2013}

Published: 4 December 2013

\section{References}

1. Eriksson SF, Pickova J: Fatty acids and tocopherol levels in M.Longissimus dorsi of beef cattle in Sweden - a comparison between seasonal diets. Meat Sci 2007, 76:746-754.

2. Chilliard Y, Glasser F, Ferlay A, Bernard L, Rouel J, Doreau M: Diet, rumen biohydrogenation and nutritional quality of cow and goat milk fat. Eur J Lipid Sci Technol 2007, 109:828-855.

3. Feussner I, Wasternack C: The lipoxygenase pathway. Annu Rev Plant Biol 2002, 53:275-297.

4. Noci F, Monahan FJ, Scollan ND, Moloney AP: The fatty acid composition of muscle and adipose tissue of steers offered unwilted or wilted grass silage supplemented with sunflower oil and fish oil. Br J Nutr 2007, 97:502-513.

5. Mo M, Selmer-Olsen I, Randby AT, Aakre SE, Asmyhr A: New fermentation products in grass silage and their effects on feed intake and milk taste, Proceedings of the 10th International Symposium on Forage Conservation. Brno, CZ: Nutrivet Ltd; 2001.

6. Krizsan SJ, Westad F, Adnoy T, Odden E, Aakre SE, Randby AT: Effect of volatile compounds in grass silage on voluntary intake by growing cattle. Anim 2007, 1:283-292.

7. Umana R, Staples CR, Bates DB, Wilcox CJ, Mahanna WC: Effects of a microbial inoculant and (or) sugarcane molasses on the fermentation aerobic stability, and digestibility of bermudagrass ensiled at two moisture contents. J Anim Sci 1991, 69:4588-4601.

8. Sheperd AC, Maslank M, Quinn D, Kung L: Additives containing bacteria and enzymes for alfalfa silage. J Dairy Sci 1995, 78:565-572.

9. Bureenok S, Namihira T, Kawamoto Y, Nakada T: Additive effects of fermented juice of epiphytic lactic acid bacteria on the fermentative quality of guinea grass (Panicum maximum Jacq.) silage. Grass/ Sci 2005, 51:243-248.

10. Dewhurst RJ, Scollan ND, Youell SJ, Tweed JKS, Humphreys MO: Influence of species, cutting date and cutting interval on the fatty acid composition of grasses. Grass Forage Sci 2001, 56:68-74.

11. Dewhurst RJ, King PJ: Effects of extended wilting, shading and chemical additives on the fatty acids in laboratory grass silages. Grass Forage Sci 1998, 53:219-224. 
12. Boufaued H, Chouinard PY, Tremblay GF, Petit HV, Michaud R, Belanger G: Fatty acids in forages. I. Factors affecting concentrations. Can J Anim SCi 2003, 83:501-511.

13. Shingfield K, Reynolds CK, Lupoli B, Toivonen V, Yurawecz MP, Delmonte P, Griinari JM, Grandison AS, Beever DE: Effect of forage type and proportion of concentrate in the diet on milk fatty acid composition in cows given sunflower oil and fish oil. Anim Sci 2005, 80:225-238.

14. Arvidsson K, Gustavsson AM, Martinsson K: Effects of conservation method on fatty acid composition of silage. Anim Feed Sci Technol 2009, 148:241-252.

15. Lourenco M, Van Ranst G, Fievez V: Difference in extent of lipolysis in red or white clover and ryegrass silages in relation to polyphenol oxidase activity. Comm Agric Appl Biol Sci 2005, 70:169-172.

16. Lee MRF, Scott MB, Tweed JKS, Minchin FR, Davies DR: Effects of polyphenol oxidase on lipolysis and proteolysis of red clover silage with and without a silage inoculant (Lactobacillus plantarum L54). Anim Feed Sci Technol 2008, 144:125-136.

17. Noziere P, Graulet B, Lucas A, Martin B, Grolier P, Doreau M: Carotenoids for ruminants: from foragrs to dairy products. Anim Feed Sci Technol 2006, 131:418-450.

18. Surrey K: Spectrophotometric determination of lipoxygenase activity. Plant Physiol 1964, 38:65-70.

19. Bradford MM: A rapid and sensitive method for the quantitation of microgram quantities of protein utilizing the principle of protein-dye binding. Anal Biochem 1976, 72:248-254.

20. Raes K, de Smet S, Demeyer D: Effect of double-muscling in Belgian blue young bulls on the intramuscular fatty acid composition with emphasis on conjugated linoleic acid and polyunsaturated fatty acids. Anim Sci 2001, 73:253-260.

21. Bird RP, Draper HH: Comparative studies on different methods of malonaldehyde determination. Method Enzymol 1984, 105:299-305.

22. Owens VN, Albrecht KA, Muck RE, Duke SH: Protein degradation and fermentation characteristics of red clover and alfalfa silage harvested with varying levels of total nonstructural carbohydrates. Crop Sci 1999, 39:1873-1880.

23. Broderica GA, Kang JH: Automated simultaneous determination of ammonia and total amino acids in ruminal fluid and in vitro media. J Dairy Sci 1980, 63:64-75.

24. Association of Official Analytical Chemists: Official Methods of Analysis of the Association of Official Analytical Chemists. 16th edition. Arlington, VA: Association of Analytical Communities; 1995.

25. Van Soest PJ, Robortson JB, Lewis BS: Methods for dietary fiber, neutral detergent fiber and non starch polysaccharides in relation to animal nutrition. J Dairy Sci 1991, 73:2583-3593.

26. Deriaz RE: Routine analysis of carbohydrates and lignin in herbage. J Sci Food Agric 1961, 12:152-160

27. Institute Inc SAS: SAS/Genetics ${ }^{T M}$ 9.1.3 User's Guide. Cary, NC: SAS Institute Inc; 2005.

28. Castle ME, Watson JN: The relationship between the DM content of herbage for silage making and effluent production. Grass Forage Sci 1973, 28:135-138

29. Rooke JA, Hatfield RD: Biochemistry of ensiling. In Silage Science and Technology. Edited by Buxton DR, Muck RE, Harrison JH. Madison: ASA Inc; 2003.

30. Thompson JE, Froese CD, Madey E, Smith MD, Hong Y: Lipid metabolism during plant senescence. Prog Lipid Res 1998, 37:119-141.

31. Kanner J, Hazan B, Doll L: Catalytic 'free' iron ions in muscle foods. J Agric Food Chem 1991, 36:412-415.

32. Elgersma A, Ellen $G$, van der Horst $H$, Muuse BG, Boer $H$, Tamminga S: Influence of cultivar and cutting date on the fatty acid composition of perennial ryegrass (Lolium perenne L.). Grass Forage Sci 2003, 58:323-331.

33. Lee MRF, Winters AL, Scollan ND, Dewhurst RJ, Theodorou MK, Minchin FR Plant-mediated lipolysis and proteolysis in red clover with different polyphenol oxidase activities. J Sci Food Agric 2004, 84:1639-1645.

34. Van Ranst G, Fievez V, De Riek J, Van Bockstaele E: Influence of ensiling forages at different dry matters and silage additives on lipid metabolism and fatty acid composition. Anim Feed Sci Technol 2009, 150:62-74.

35. Elgersma A, Ellen G, van der Horst H, Muuse BG, Boer H, Tamminga S: Comparison of the fatty acid composition of fresh and ensiled perennial ryegrass (Lolium perenne L.), affected by cultivar and regrowth interval. Anim Feed Sci Tech 2003, 108:191-205.
36. Zhong QX, Glatz CE: Enzymatic assay method for evaluating the lipase activity in complex extracts from transgenic corn seed. J Agric Food Chem 2006, 54:3181-3185.

37. Kubow S: Toxicity of dietary lipid peroxidation products. Trends Food SCi Technol 1990, 1:67-71.

38. Bozkurt H: Utilization of natural antioxidants: green tea extract and Thymbraspicata oil in Turkish dry-fermented sausage. Meat Sci 2006, 73:442-450

39. Naveena B, Sen A, Kingsly R, Singh D, Kondaiah N: Antioxidant activity of pomegranate rind powder extract in cooked chicken patties. International J Food Sci and Technol 2008, 43:1807-1812.

40. Cuverlier ME, Berset C, Richard H: Use of a new test for determining comparative antioxidant activity of butylated hydroxyanisole, butylated hydroxytoluene, alpha- and gamma-tocopherols and extract from rosemary and sage. Sci Aliment 1990, 10:797-806.

41. Charmley E, Nicholson JWG: Influence of dietary fat source on oxidative stability and fatty acid composition of milk from cows receiving a low or high level of dietary vitamin E. Can J Anim Sci 1994, 74:657-664.

42. Focant M, Mignolet $\mathrm{E}$, Marique M, Clabots F, Breyne T, Dalemans D, Larondelle $Y$ : The effect of vitamin E supplementation of cow diets containing rapeseed and linseed on the prevention of milk fat oxidation. J Dairy Sci 1998, 81:1095-1101.

43. Min DB, Boff JM: Chemistry and reaction of singlet oxygen in foods. Comprehensive Reviews in Food Science and Food Satefy 2002, 1:28-72.

44. Gordon MH: The development of oxidative rancidity in foods. In Antioxidants in food practical applications. Edited by Pokorny J, Yanishlieva N, Gordon M. Cambridge: Woodhead Pubshing Limited; 2001.

45. Frankel EN: Free radical oxidation. Lipid oxidation. Scotland: The Oily Press Ltd; 1998.

doi:10.1186/2049-1891-4-48

Cite this article as: Han and Zhou: Effects of ensiling processes and antioxidants on fatty acid concentrations and compositions in corn silages. Journal of Animal Science and Biotechnology 2013 4:48.

\section{Submit your next manuscript to BioMed Central and take full advantage of:}

- Convenient online submission

- Thorough peer review

- No space constraints or color figure charges

- Immediate publication on acceptance

- Inclusion in PubMed, CAS, Scopus and Google Scholar

- Research which is freely available for redistribution

Submit your manuscript at www.biomedcentral.com/submit
C Biomed Central 